University of Nebraska - Lincoln

DigitalCommons@University of Nebraska - Lincoln

Nebraska Cooperative Fish \& Wildlife Research Nebraska Cooperative Fish \& Wildlife Research Unit -- Staff Publications

2006

\title{
When landscaping goes bad: the incipient invasion of Mahonia bealei in the southeastern United States
}

Craig R. Allen

U.S. Geological Survey, callen3@unl.edu

Ahjond S. Garmestani

South Carolina Cooperative Fish and Wildlife Research Unit, garmestani.ahjond@epa.gov

Jill A. LaBram

South Carolina Cooperative Fish and Wildlife Research Unit

Amanda E. Peck

South Carolina Cooperative Fish and Wildlife Research Unit

Luanna B. Prevost

Clemson University

Follow this and additional works at: https://digitalcommons.unl.edu/ncfwrustaff

Part of the Other Environmental Sciences Commons

Allen, Craig R.; Garmestani, Ahjond S.; LaBram, Jill A.; Peck, Amanda E.; and Prevost, Luanna B., "When landscaping goes bad: the incipient invasion of Mahonia bealei in the southeastern United States" (2006). Nebraska Cooperative Fish \& Wildlife Research Unit -- Staff Publications. 18.

https://digitalcommons.unl.edu/ncfwrustaff/18

This Article is brought to you for free and open access by the Nebraska Cooperative Fish \& Wildlife Research Unit at DigitalCommons@University of Nebraska - Lincoln. It has been accepted for inclusion in Nebraska Cooperative Fish \& Wildlife Research Unit -- Staff Publications by an authorized administrator of DigitalCommons@University of Nebraska - Lincoln. 


\title{
When landscaping goes bad: the incipient invasion of Mahonia bealei in the southeastern United States
}

\author{
Craig R. Allen ${ }^{1, *}$, Ahjond S. Garmestani ${ }^{2}$, Jill A. LaBram ${ }^{2}$, Amanda E. Peck ${ }^{2}$ \\ \& Luanna B. Prevost ${ }^{3}$ \\ ${ }^{1}$ USGS - South Carolina Cooperative Fish and Wildife Research Unit; ${ }^{2}$ South Carolina Cooperative Fish \\ and Wildlife Research Unit; ${ }^{3}$ Department of Biological Sciences, Clemson University, Clemson, SC 29634, \\ USA; *Author for correspondence (e-mail: allencr@clemson.edu; fax: +1-864-656-1034)
}

Received 8 July 2004; accepted in revised form 3 September 2004

Key words: horticulture, landscaping, Mahonia bealei, non-indigenous species, ornamentals, woodlots

\begin{abstract}
Woodlots are forest islands embedded within an urban matrix, and often represent the only natural areas remaining in suburban areas. Woodlots represent critical conservation areas for native plants, and are important habitat for wildlife in urban areas. Invasion by non-indigenous (NIS) plants can alter ecological structure and function, and may be especially severe in remnant forests where NIS propagule pressure is high. Woody shrubs in the Family Berberidaceae have been well documented as invaders of the forest-urban matrix in North America. Mahonia bealei (Berberidaceae) is a clonal shrub native to China, and is a popular ornamental in the Southeastern United States. Mahoni bealei is listed as "present" on some local and state floras, but almost nothing is known regarding its invasion potential in the United States. We sampled 15 woodlots in Clemson, South Carolina, to assess the invasion of $M$. bealei and other woody non-indigenous species (NIS). M. bealei invaded $87 \%$ of the woodlots surveyed and species richness of NIS on these woodlots varied from 5 to 14. Stepwise-multiple regression indicated that less canopy cover and older $M$. bealei predicted greater abundance of $M$. bealei, and that not all subdivisions were equally invaded $\left(P<0.0001 ; r^{2}=0.88\right)$. The impact of $M$. bealei on native flora and fauna may be considerable, and it is likely to continue to spread in the Southeastern United States. $M$. bealei should be recognized as an aggressive invader in the Southeastern United States, with the potential for negative impacts on native flora and fauna.
\end{abstract}

\section{Introduction}

Invasion by non-indigenous (NIS) plants can alter ecological structure and function, and is one of the primary threats to rare and endangered species (Gordon 1998). The majority of woody invasive plants in the United States were introduced for horticultural purposes, including landscaping (Reichard and White 2001). Many NIS plants were introduced into the United States as ornamentals (e.g., Chinese privet, Ligustrum sinense; Japanese honeysuckle, Lonicera japonica; Nandina, Nandina domestica). L. sinense has been characterized as an aggressive invader in the southeastern USA, with the ability to reduce growth of native species (Merriam and Feil 2002). Lonicera japonica is tolerant of shade and can overwhelm forest edges once established (Robertson et al. 1994).

The southern Piedmont region of the United States, $161,430 \mathrm{~km}^{2}$ between the Appalachian Mountains and the Coastal Plain, extends from 
Virginia in the northeast to east-central Alabama in the southwest. Regional population growth has contributed to the conversion of rural, forested or agricultural land-uses and land-covers to urban and suburban uses in many areas. The southern Piedmont is expected to experience a greater loss of forested land than other regions of the south (Wear and Greis 2001). High rates of forest fragmentation are expected to increase, as human population growth accelerates in urban, suburban and rural communities (Wear and Greis 2001). As human population growth and developmental sprawl continue in this region, concomitant changes in ecosystem integrity and the production of ecological goods and services can be expected, including losses in water availability and quality, loss of native habitats, loss of biological diversity, and conversion of forest land to non-natural states. As the southern Piedmont further fragments and suburbanizes, remnant woodlots may become increasingly important in maintaining the integrity and resilience of the linked human-ecological system.

Woodlots are characterized as forest islands within an urban matrix, and often represent the only semi-natural areas remaining in suburban areas (Levenson 1981; Boutin and Jobin 1998). Forest "islands" and fragments may be more easily invaded than continuous forests (Fine 2002). However, empirical evidence for island invasibility is mixed (Lonsdale 1999). Woodlots can have twice as many native plant species as old fields, wooded fencerows, ditches, and hay fields (Freemark et al. 2002). A small patch of forest (4 ha) may be sufficient to sustain native, forest-interior plants (Usher 1987). Therefore, woodlots represent critical conservation areas for native plants (Boutin and Jobin 1998). Additionally, woodlots represent important habitat for wildlife in urban areas (Matthiae and Stearns 1981). Understanding the role of NIS plants in woodlots is especially important, as they may have a greater impact on remnant woodlots in urbanized areas (Miller and Hobbs 2002) than in more extensive patches.

Woody shrubs in the Family Berberidaceae (Barberry family) have been well documented as invaders of the forest-urban matrix in North America (Ehrenfeld 1997, 1999; Silander and Klepeis 1999). Invasion by woody shrubs may create a shift in forest under- and mid-story composition, which in turn may alter primary production, nutrient cycling, and carbon storage (Jackson et al. 2002). Mahonia bealei (Berberidaceae) is a clonal shrub native to China. It is a popular ornamental because of its bright yellow, slightly fragrant flowers that appear in late winter or spring and its dark blue berries that remain through the summer. M. bealei can grow to $4 \mathrm{~m}$ tall (Basinger 2001). The leaves are pinnately compound with 9-15 spiny leaflets, giving the plant a width of approximately $1-2.5 \mathrm{~m}$. $M$. bealei is recommended as a wildlife attractant by several resource management agencies in the southeastern United States, yet the Southeast Exotic Pest Plant Council (www.se-eppc.org) lists it as a rank 2 (significant threat) NIS plant. Plants of this rank possess characteristics of an invasive species but are not currently considered to spread easily into native plant communities. $M$. bealei is listed as present on several local or state floras (Basinger 2001; Bowen et al. 2002; Leidolf et al. 2002) and is readily available at nurseries, but almost nothing is known regarding its invasion potential in the United States. A closely related congener, Mahonia aquifolium, is recognized as an aggressive invader in central Europe (Auge and Brandl 1997).

Here we: (1) document the presence of $M$. bealei and NIS, (2) assess the abundance and structure of invasive $M$. bealei populations, and (3) determine predictors of $M$. bealei abundance and overall NIS richness in southern Piedmont woodlots.

\section{Materials and methods}

We randomly selected five woodlots in each of three suburban subdivisions in the city limits of Clemson, South Carolina, USA. Between January and April, 2003, we collected information on the invasion of $M$. bealei and other woody NIS on these 15 replicates. For each replicate we recorded the adjacent land use (house, road, or undeveloped) surrounding the lot in the four cardinal directions, the age of the oldest and newest adjacent houses, size of the woodlot (ha), slope, aspect, species richness of NIS, and percent cover of M. bealei and English ivy (Hedera helix). Lot 
size was determined from GIS coverage of ownership parcels, and land use was determined by observation. Adjacent land use was quantified categorically, by assigning a house or road a value of one and native woodlands a 0 , and values were totaled for each site, with the highest land use value equal to four. We also documented the number and age (by counting internodes) of genets of all $M$. bealei, as well as presence or absence of flowers, by noting persistent rachides of the inflorescence. Counting internodes clearly assessed age for plants $<7$ years of age and for recent growth (up to 7 years) on older plants, based on the observation of growth of specimens over several years and the frequent persistence of rachides of not only the current year but also previous years. Estimates of age for plants $>7$ years of age were less certain, and our age estimates are conservative for older specimens.

Within each replicate we established two 78.5$\mathrm{m}^{2}$ circular plots at the end of two $15-\mathrm{m}$ transects diagonally opposite from each other at opposite corners of a lot. In each plot, all native and NIS woody species were identified, and percent coverage of dominant native and NIS species was documented in the ground $(<1.5 \mathrm{~m}$ height), midstory $(1.5-6 \mathrm{~m})$ and canopy $(>6 \mathrm{~m})$ strata in five categories $(0-20,21-40,41-60,61-80$, and 81$100 \%)$. For vertical structure, we used a $2.5-\mathrm{m}$ vertical structure board to record the percent of the five sections of the board covered (same 5 categories) at $0.5 \mathrm{~m}$ intervals, observed at a distance of $15 \mathrm{~m}$ from the cardinal directions (Nudds 1977). Percent canopy cover was determined using a densiometer. Structure and cover at the two plots were averaged to get a total for each site.

We used PROC REG to develop two separate stepwise multiple regression models in SAS (SAS Institute 2000) to determine if any of the habitat characteristics predicted $M$. bealei abundance and NIS richness. The independent variables used to predict abundance of $M$. beale $i$ were size of woodlot, oldest adjacent house, subdivision, slope, NIS richness, canopy cover, vertical structure, non-native ground cover, percent $H$. helix cover, and age of oldest $M$. bealei. The independent variables used in the model to predict NIS richness were size of woodlot, oldest adjacent house, slope, abundance of $M$. bealei, canopy cover, vertical structure, percent $H$. helix cover, and age of oldest $M$. bealei. Assumptions of equal variance and normality were tested with a Levene median test and a Kolmogorov-Smirnov distance equation, respectively. Mahonia abundance was not normally distributed, and we used a square root transformation to normalize the data.

\section{Results}

Our 15 sites, and the subdivisions in which they were embedded, were typical of older subdivisions in the southern Piedmont. Tree cover was high, even outside remnant woodlots. Woodlots varied in area from 0.05 to 0.36 ha (Table 1). All woodlots were invaded to some degree by NIS. $L$. sinense occurred on all sites. H. helix and L. japonica occurred on 14 sites, while $N$. domestica and M. bealei occurred on 13 sites (Table 2). Species richness of NIS varied from 5 to 14 .

The $M$. bealei abundance at a site ranged from 0 (2 sites) to 291, with a mean of 47 and a median of 14. The oldest individual was at least 15 years of age. In one subdivision, M. bealei was present in all 5 woodlots and abundance ranged from 43 to 291 . These sites had more $M$. bealei than 9 of the 10 remaining sites. Conversely, in another subdivision, only 3 of the sites contained $M$. bealei and the abundance was much lower ( $\leq 8$; Table 1). M. bealei individuals were not restricted to the edge of woodlots, and were found up to $61 \mathrm{~m}$ from an edge. The independent variables "oldest adjacent house" and "percent $H$. helix" were removed to reduce multi-collinearity. A significant three variable model was determined $\left(P<0.0001 ; r^{2}=0.88\right)$. Significant predictor variables were "subdivision C" $(P=0.0094)$ "age of oldest $M$. bealei" $(P=0.0007$; Figure 1$)$ and "canopy cover" $(P=0.0179$; Figure 2$)$ on a particular woodlot. Less canopy cover and older $M$. bealei predicted greater abundance, with a greater number of $M$. bealei in the younger age classes (Table 3).

The earliest evidence of flowering in $M$. bealei occurred at age two $(2 \%)$. By age five $60 \%$ of individuals flowered (Figure 3). The population structure on our sites suggests rapid population 
Table 1. Results from 15 replicate suburban woodlots sampled between January and April, 2003 in Clemson, South Carolina.

\begin{tabular}{|c|c|c|c|c|c|c|c|c|c|c|}
\hline Plot & Sub-division & $\begin{array}{l}\text { Size of } \\
\text { woodlot } \\
\text { (hectares) }\end{array}$ & $\begin{array}{l}\text { M. bealei } \\
\text { abundance } \\
\text { (\# of genets) }\end{array}$ & $\begin{array}{l}\text { Age of oldest } \\
\text { M. bealei } \\
\text { (years) }\end{array}$ & \# NIS & $\begin{array}{l}\text { \% cover } \\
\text { ivy }\end{array}$ & $\begin{array}{l}\text { canopy } \\
\text { cover }(\%)\end{array}$ & $\begin{array}{l}\text { Age of oldest } \\
\text { adjacent } \\
\text { house }\end{array}$ & $\begin{array}{l}\text { Age of newest } \\
\text { adjacent } \\
\text { house }\end{array}$ & $\begin{array}{l}\text { Slope } \\
\left({ }^{\circ}\right)\end{array}$ \\
\hline 1 & A & 0.219 & 23 & 10 & 13 & 55 & 96 & 52 & 11 & 15 \\
\hline 2 & A & 0.129 & 14 & 10 & 13 & 70 & 94 & 55 & 35 & 3 \\
\hline 3 & A & 0.357 & 4 & 10 & 12 & 3 & 95 & 50 & 24 & 23 \\
\hline 4 & A & 0.244 & 54 & 15 & 12 & 65 & 96 & 50 & 24 & 12 \\
\hline 5 & A & 0.076 & 6 & 9 & 10 & 90 & 95 & 39 & 26 & 20 \\
\hline 6 & B & 0.166 & 8 & 9 & 5 & 0 & 95 & 28 & 21 & 5 \\
\hline 7 & B & 0.184 & 0 & 0 & 10 & 7 & 92 & 53 & 43 & 7 \\
\hline 8 & B & 0.114 & 4 & 8 & 7 & 30 & 93 & 33 & 27 & 15 \\
\hline 9 & B & 0.155 & 2 & 5 & 7 & 3 & 87 & 23 & 14 & 1 \\
\hline 10 & B & 0.170 & 0 & 0 & 8 & 2 & 85 & 24 & 17 & 3 \\
\hline 11 & $\mathrm{C}$ & 0.180 & 64 & 12 & 10 & 20 & 92 & 36 & 17 & 15 \\
\hline 12 & $\mathrm{C}$ & 0.125 & 291 & 12 & 9 & 100 & 85 & 34 & 13 & 5 \\
\hline 13 & $\mathrm{C}$ & 0.047 & 43 & 7 & 10 & 30 & 91 & 36 & 4 & 10 \\
\hline 14 & C & 0.125 & 84 & 12 & 14 & 60 & 94 & 34 & 21 & 8 \\
\hline 15 & C & 0.125 & 108 & 10 & 11 & 20 & 91 & 34 & 21 & 10 \\
\hline
\end{tabular}

On these sites information was collected on the invasion of Mahonia bealei and other woody non-indigenous species (NIS).

growth. An exponential growth model fit the data better $\left(r^{2}=0.97\right)$ than a simple linear model $\left(r^{2}=0.78\right)$.

In the model of NIS richness we removed the variable "age of the oldest $M$. bealei" to reduce multi-collinearity among variables. Overall NIS richness was best predicted by a single variable model (age of the oldest adjacent house) $\left(P=0.005 ; r^{2}=0.47\right)$ (Table 4 and Figure 4$)$ :

Table 2. Non-indigenous species present in suburban woodlots sampled in Clemson, South Carolina between January and April, 2003.

\begin{tabular}{lll}
\hline Common name & Scientific name & $\begin{array}{l}\text { Number of } \\
\text { sites present }\end{array}$ \\
\hline Chinese privet & Ligustrum sinense & 15 \\
English ivy & Hedera helix & 14 \\
Japanese honeysuckle & Lonicera japonica & 14 \\
Mondo grass & Ophiopogon planiscapus & 14 \\
Leatherleaf mahonia & Mahonia bealei & 13 \\
Nandina & Nandina domestica & 13 \\
Thorny olive & Elaeagnus pungens & 12 \\
Japanese holly & Ilex crenata & 11 \\
Vinca minor & Vinca minor & 10 \\
Multi-flora rose & Rosa multiflora & 9 \\
Super dwarf & Ophiopogon japonicus & 8 \\
mondo grass & & \\
Japanese privet & Ligustrum japonicum & 7 \\
Red top Photinia & Photinia glabra & 5 \\
Vinca major & Vinca major & 2 \\
Japanese acuba & Acuba japonica & 2 \\
Chinese holly & Ilex cornuta & 1 \\
Japanese pachysandra & Pachysandra terminalis & 1 \\
\hline
\end{tabular}

\section{Discussion}

Mahonia bealei has invaded $87 \%$ of the suburban woodlots we surveyed in the Clemson, South Carolina area. The abundance of $M$. bealei was predicted by the age of the $M$. bealei on a woodlot and canopy cover, and also varied by subdivision. All our sites are best considered closed-canopy forest (cover range 85-96\%), and it appears that $M$. bealei can exploit very small light gaps and does well in very low light conditions. This suggests that $M$. bealei is not only a threat to remnant woodlots in the piedmont, but

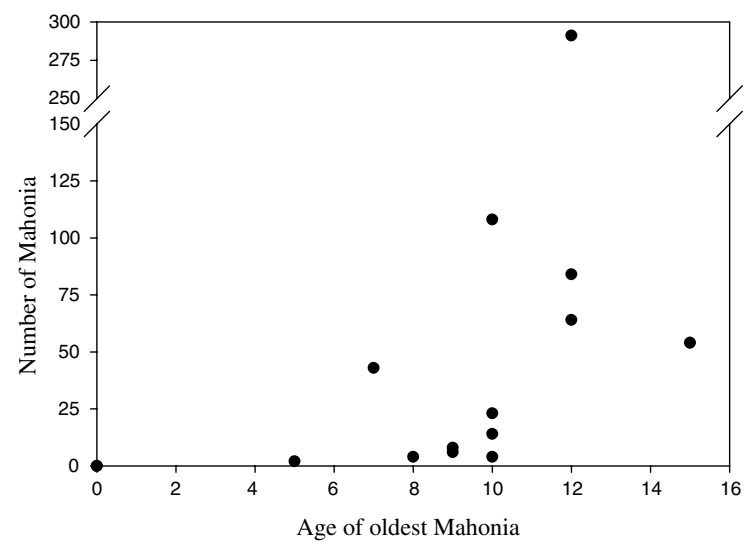

Figure 1. Relationship between the abundance of Mahonia beale $i$ and age of oldest $M$. bealei on 15 remnant woodlots in the southern Piedmont of the United States. 


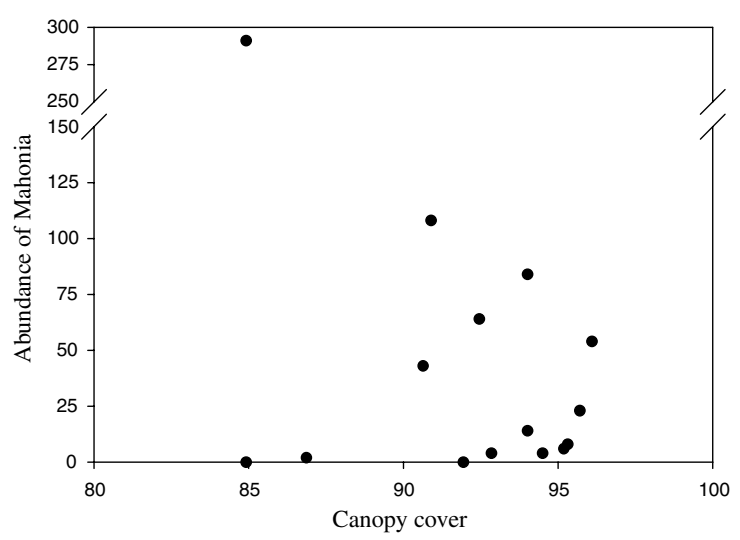

Figure 2. Relationship between the abundance of Mahonia bealei and canopy cover on 15 remnant woodlots in the southern Piedmont of the United States.

to more extensive forests as well. The population structure we documented suggests that these sites have been recently invaded, and that rapid population growth of $M$. bealei can be expected.

A closely related congener of $M$. bealei is the Oregon grape ( $M$. aquifolium), native to the western USA Mahonia aquifolium has been documented as an aggressive invader in Germany and other areas in central Europe (Auge and Brandl 1997). It is used as a host plant by herbivores and pathogens native to its new habitat (Auge et al. 1997). M. aquifolium has several characteristics proposed as indicators of increased success of invasion for plants: high seed production and a lack of specialist herbivores in its new habitat (Soldaat and Auge 1998), and small seed mass (Rejmanek 1996). Additionally, it has been suggested that cultivated Mahonia have higher reproductive potential than their wild relatives, because of the likelihood that the plants have been bred for more flowers and fruit (Soldaat and Auge 1998). The success of $M$. aquifolium in Germany suggests that $M$. bealei may become a successful, aggressive invader in North America.

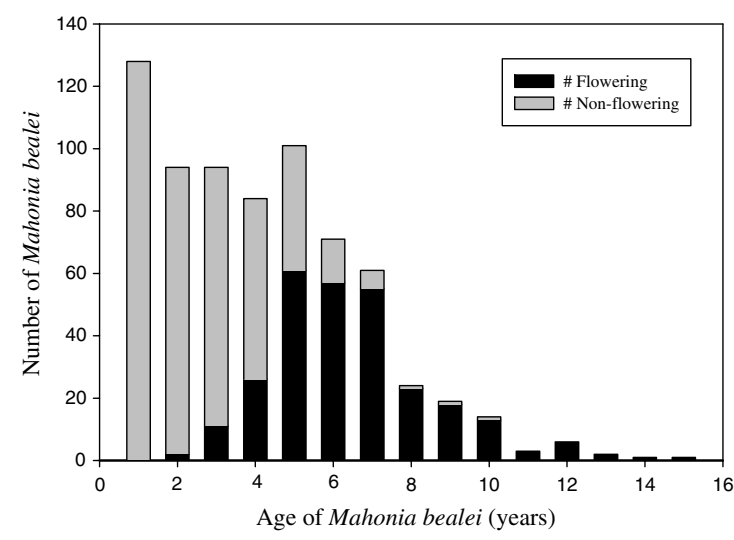

Figure 3. Population structure of Mahonia bealei on 15 remnant woodlots in the southern Piedmont of the United States.

Japanese barberry (Berberis thunbergii), a woody, clonal shrub in the same Family (Berberidaceae) as $M$. bealei, also utilizes multiple forms of vegetative and seed-based population growth (Ehrenfeld 1999). It has been characterized as one of the most widely known and planted non-indigenous shrubs in the United States (Silander and Klepeis 1999) and has been highly successful at spreading into the forest matrix and producing dense, persistent populations (Ehrenfeld 1997). As $M$. bealei plants become older, reproduction by seed and clonal ramets increases leading to increased plant density. Most $M$. bealei on our sites were at least 4 years old before reaching sexual maturity. A similar period to maturity was observed with amur honeysuckle (Lonicera maackii), an invasive shrub in the eastern United States and Canada (Deering and Vankat 1999).

Disturbance along with continued and widespread planting for ornamental purposes may lead to greater $M$. bealei invasion of woodlots via propagule pressure (Fine 2002). Propagule pressure can be important in determining the success of establishment and spread of invasive species (Williamson and Fitter 1996). Edge effects in

Table 3. Stepwise-multiple regression model of predictors of Mahonia bealei abundance.

\begin{tabular}{|c|c|c|c|c|c|c|}
\hline Variable & Parameter estimate & Standard error & $F$-value & $P$-value & Partial $r^{2}$ & Overall $r^{2}$ \\
\hline Intercept & 42.822 & 15.785 & 7.36 & 0.0202 & & 0.875 \\
\hline Subdivision C & 4.096 & 1.304 & 9.87 & 0.0094 & 0.634 & \\
\hline Oldest $M$. bealei & 0.778 & 0.168 & 21.37 & 0.0007 & 0.155 & \\
\hline Canopy cover & -0.496 & 0.178 & 7.72 & 0.0179 & 0.087 & \\
\hline
\end{tabular}


Table 4. Stepwise-multiple regression model of predictors of non-indigenous species (NIS) richness.

\begin{tabular}{lllrrr}
\hline Variable & $\begin{array}{l}\text { Parameter } \\
\text { estimate }\end{array}$ & $\begin{array}{l}\text { Standard } \\
\text { error }\end{array}$ & $F$-value & $P$-value & $r^{2}$ \\
\hline $\begin{array}{l}\text { Intercept } \\
\text { Age of oldest }\end{array}$ & 3.689 & 1.925 & 3.67 & 0.078 & 0.475 \\
house & & 0.048 & 11.76 & 0.005 & \\
\hline
\end{tabular}

a woodlot, manifested in changes in light, temperature, and litter moisture can be detected up to $50 \mathrm{~m}$ into woodlots (Matlack 1993). Mahonia repens are known to exhibit a dramatic decrease in photosynthetic capacity in partially shaded conditions (Logan et al. 1998). However, survival of $B$. thunbergii was found to drop significantly only at very low light levels (Silander and Klepeis 1999). Our data suggest M. bealei can tolerate low light conditions.

We observed honeybees and ants (Prenolepsis imparins) visiting the flowers of $M$. bealei, with the majority of bees coated with pollen. Pollination and dispersal have been documented in related species. The pollination of the flowers of $B$. thunbergii is effected by small and large bees, Adrenids and Bombus spp., respectively (Martin et al. 1951; Lebuhn and Anderson 1994). Bumblebees (Bombus spp.) have also been documented visiting Mahonia spp. in the United Kingdom (Fussell and Corbet 1992). The flowers of M. japonica, another close relative of $M$. bealei, are utilized by blackcaps (Sylvia atricapilla) and

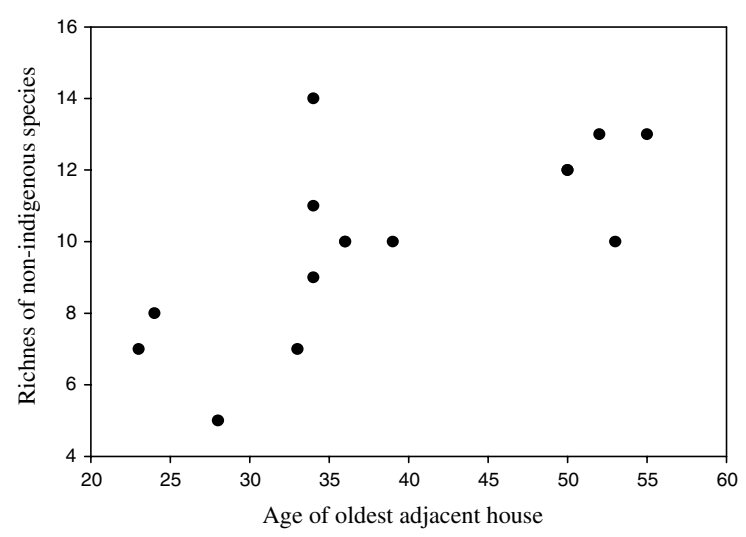

Figure 4. Relationship between species richness of woody non-indigenous species on 15 remnant woodlots in the southern Piedmont of the United States and age of the oldest adjacent home. blue tits (Parus caeruleus) in the United Kingdom (Harrup 1998).

For $M$. aquifolium, dispersal by vertebrates has been identified as a necessity for the colonization of new sites, and to buffer against the mortality of seedlings beneath the canopy of adults (Soldaat and Auge 1998). A congener of M. bealei, M. repens, is spread by black bears (Ursus americanus) in the western USA (Auger et al. 2002). Bears can transport huge numbers of seeds for dispersal, and one male is known to have defecated approximately $60,000 \mathrm{M}$. repens seeds within $24 \mathrm{~h}$ (Auger et al. 2002). It is estimated that those seeds accounted for 10,000 individual $M$. repens fruits. Bears also may be effective long distance dispersers of Mahonia, and their digestive tracts may have a role in accelerating germination times (Auger et al. 2002). The berries of $B$. thunbergii are eaten infrequently by most songbirds (Martin et al. 1951; Lebuhn and Anderson 1994). Other western Berberis species are dispersed by white-tailed and mule deer (Martin et al. 1951). Wild turkeys and grouse are also known to utilize the berries (Ehrenfeld 1997). Although we have no direct evidence, we assume that warblers and many other passerines in the eastern United States could pollinate $M$. bealei and disperse the fruits produced by the shrubs. Dispersal by vertebrates with their potential for long distance movements increases the probability of invasion by $M$. bealei into native forests.

Little is known about the effects of urbanization on ecosystems, communities, species, and populations (Cairns 1988). Woodlots can be areas of high plant diversity (Freemark et al. 2002) and supply habitat for birds in urban areas (Savard et al. 2000). With increases in the wildland-urban interface and forest fragmentation, "forest island" suburban woodlots may serve as refuges for native plants (Honnay et al. 1999) and animals in urbanized areas. When NIS invade these areas, ecological structure and function may be modified. The spread of $M$. bealei may shade areas beneath the plant, and prevent the growth of native mid-story species, such as flowering dogwood (Cornus florida). This growth habit is common to other members of the barberry family such as $B$. thunbergii and $M$. aquifolium. We documented invasion by a 
variety of species on woodlots, but the interactions among these species are not clear (Simberloff and Von Holle 1999).

The spread of $M$. bealei should be studied at the regional as well as local scale to document its current distribution and potential for spread. We have observed $M$. bealei in more extensive woodlands outside of suburban areas in western South Carolina. It is important to understand the population dynamics of this plant while in the early stages of invasion. Invasive species often undergo a lag phase during which spread is often localized (Hobbs and Humphries 1995). With the reproductive pattern of $M$. bealei, once maturity is reached by colonizers and their progeny, the growth of each population and potential for spread increases exponentially (Auge and Brandl 1997).

Additional collaborative efforts are needed to reduce horticulture as a pathway of invasive plant introduction and spread. Gardening is a top hobby in the United States and the public needs to be educated about the impact of invasive species (Reichard and White 2001). M. bealei are readily available from nurseries and other retail establishments in the Clemson, South Carolina area. Further, the shrub is presented to the public as an excellent species for attracting birds to suburban yards in the winter by horticulturalists (Ellis 1995; Miller 2002; Pfeiffer 2002), and by state agencies (Black 1999; Gilman 1999). The impact on native flora and fauna could be considerable with the continued spread of $M$. beale $i$ in the southeastern United States. M. bealei should be recognized as an aggressive invader with the potential to negatively impact native flora and fauna in the southeastern United States.

\section{Acknowledgements}

The South Carolina Cooperative Fish and Wildlife Research Unit is jointly supported by a cooperative agreement among the United States Geological Survey/Biological Resources Division, South Carolina Department of Natural Resources, Clemson University, and the Wildlife Management Institute. We would like to thank J. Walker and H. Auge for helpful suggestions, P. McMillan for plant identification, J. Zettler for ant identification, private landowners for access to woodlots, and the Clemson Land Planning office for maps and GIS coverage of the area. This manuscript was improved by helpful comments from K. Manry and three anonymous reviewers.

\section{References}

Auge H and Brandl R (1997) Seedling recruitment in the invasive clonal shrub, Mahonia aquifolium Pursh (Nutt.). Oecologia 110: 205-211

Auge H, Brandl R and Fussy M (1997) Phenotypic variation, herbivory and fungal infection in the clonal shrub Mahonia aquifolium (Berberidaceae). Mitt. Dtsch. Ges. allg. angew. Ent 11: 747-750

Auger J, Meyer SE and Black HL (2002) Are American black bears (Ursus americanus) legitimate seed dispersers for fleshy-fruited shrubs? American Midland Naturalist 147: 352 367

Basinger M (2001) Additions to the vascular flora of Illinois. Transactions of the Illinois State Academy of Science 94: 199-205

Black RJ (1999) Selected shrubs for North Florida. Circular 500, Florida Cooperative Extension Service, Institute of Food and Agricultural Sciences, University of Florida. Revised: May 1999

Boutin C and Jobin B (1998) Intensity of agricultural practices and effects on adjacent habitats. Ecological Applications 8: 544-557

Bowen B, Johnson K, Franklin S, Call G and Webber M (2002) Invasive exotic pest plants in Tennessee. Journal of the Tennessee Academy of Science 77: 45-48

Cairns J (1988) Restoration ecology: the new frontier. In: Cairns J (ed) Rehabilitating Damaged Ecosystems, pp 1-11. CRC Press, Boca Raton, Florida

Deering RH and Vankat JL (1999) Forest colonization and development of growth of the invasive shrub Lonicera maackii. American Midland Naturalist 141: 43-50

Ehrenfeld JG (1997) Invasion of deciduous forest preserves in the New York metropolitan region by Japanese Barberry (Berberis thunbergii DC.). Journal of the Torrey Botanical Society 124: 210-215

Ehrenfeld JG (1999) Structure and dynamics of populations of Japanese barberry (Berberis thunbergii DC.) in deciduous forests of New Jersey. Biological Invasions 1: 203-213

Ellis DJ (1995) Wildlife in the winter garden. American Horticulturalist November: 16-17

Fine PVA (2002) The invasibility of tropical forests by exotic plants. Journal of Tropical Ecology 18: 687-705

Freemark KE, Boutin C and Keddy CJ (2002) Importance of farmland habitats for conservation of plant species. Conservation Biology 16: 399-412

Fussell M and Corbet S (1992) Flower usage by bumble-bees: a basis for forage plant management. Journal of Applied Ecology 29: 451-465 
Gilman EF (1999) Mahonia bealei. Fact Sheet FPS-376, Florida Cooperative Extension Service, Institute of Food and Agricultural Sciences, University of Florida

Gordon DR (1998) Effects of invasive, non-indigenous plant species on ecosystem process: lesson from Florida. Ecological Applications 8: 975-989

Harrup B (1998) Wintering blackcaps taking nectar from, and probably pollinating, Mahonia. British Birds 91: 1998

Hobbs RJ and Humphries SE (1995) An integrated approach to the ecology and management of plant invasions. Conservation Biology 9: 761-770

Honnay O, Endels P, Vereecken H and Hermy M (1999) The role of patch area and habitat diversity in explaining native plant species richness in disturbed suburban forest patches in northern Belgium. Diversity and Distributions 5: 129-141

Jackson RB, Banner JL, Jobbagy EG, Pockman WT and Wall DH (2002) Ecosystem carbon loss with woody plant invasion of grasslands. Nature 418: 623-626

Lebuhn G and Anderson GJ (1994) Anther tripping and pollen dispersing in Berberis thunbergii. American Midland Naturalist 131: 257-265

Leidolf A, McDaniel S and Nuttle T (2002) The flora of Oktibbeha County, Mississippi. SIDA-Contributions to Botany 20: 691-765

Levenson JB (1981) Woodlots as biogeographic islands in southeastern Wisconsin. In: Burgess RL and Sharpe DM (eds) Forest Island Dynamics in Man-dominated Landscapes, pp 13-39. Springer-Verlag, New York

Logan BA, Grace SC, Adams III WW and Demmig-Adams B (1998) Seasonal differences in xanthophyll cycle characteristics and antioxidants in Mahonia repens growing in different light conditions. Oecologia 116: 9-17

Lonsdale WM (1999) Global patterns of plant invasions and the concept of invasibility. Ecology 80: 1522-1536

Martin A, Zim HS and Nelson AL (1951) American Wildlife and Plants: A Guide to Wildlife Food Habits. Dover Publications, New York

Matlack GR (1993) Microenvironment variation within and among forest edge sites in the eastern United States. Biological Conservation 66: 185-194

Matthiae PE and Stearns F (1981) Mammals in forest islands in southeastern Wisconsin. In: Burgess RL and Sharpe DM (eds) Forest Island Dynamics in Man-dominated Landscapes, pp 55-66. Springer-Verlag, New York

Merriam RW and Feil E (2002) The potential impact of an introduced shrub on native plant diversity and forest regeneration. Biological Invasions 4: 369-373
Miller CB (2002) Scents of winter. Horticulture Jan./Feb.: 24

Miller JR and Hobbs RJ (2002) Conservation where people live and work. Conservation Biology 16: 330-337

Nudds TD (1977) Quantifying the vegetative structure of wildlife cover. Wildlife Society Bulletin 5: 113-117

Pfeiffer P (2002) Mahonia bealei. American Nurseryman 1: 110

Reichard SH and White P (2001) Horticulture as a pathway of invasive plant introductions in the United States. Bioscience 51: 103-113

Rejmanek M (1996) A theory of seed plant invasiveness: the first sketch. Biological Conservation 78: 171-181

Robertson DJ, Robertson MC and Tague T (1994) Colonization dynamics of four exotic plants in a northern piedmont natural area. Bulletin of the Torrey Botanical Club 121: 107-118

SAS Institute, Inc. 2000. SAS OnlineDoc®, Version 8. Cary, North Carolina

Savard JL, Clergeau P and Mennechez G (2000) Biodiversity concepts and urban ecosystems. Landscape and Urban Planning 48: 131-142

Silander JA and Klepeis DM (1999) The invasion ecology of Japanese barberry (Berberis thunbergii) in the New England landscape. Biological Invasions 1: 189-201

Simberloff D and Von Holle B (1999) Positive interactions of nonindigenous species: invasional meltdown? Biological Invasions 1: 21-32

Soldaat LL and Auge H (1998) Interactions between an invasive plant, Mahonia aquifolium, and a native phytophagous insect, Rhagoletis meigenii. In: Starfinger U, Edwards K, Kowarik I and Williamson M (eds) Plant Invasions: Ecological Mechanisms and Human Responses, pp 347 360. Backhuys Publishers, Leiden, The Netherlands

Usher MB (1987) Effects of fragmentation on communities and populations: a review with applications to wildlife conservation. In: Saunders DA, Arnold GW, Burbridge AA and Hopkins AJM (eds) Nature Conservation: The Role of Remnants of Native Vegetation, pp 103-121. Surrey Beatty and Sons Pry Ltd., Chipping Norton, New South Wales, Australia

Wear DN and Greis JG (2001) The southern forest resource assessment summary report. Southern Research Station, U.S. Department of Agriculture Forest Service

Williamson MH and Fitter A (1996) The characters of successful invaders. Biological Conservation 78: 163-170 